\title{
Editorial
}

Jennifer B. Delfino* and Maureen Kosse

\section{Racialization and the national body: (Re)defining selves and others in changing contexts of liberal democratic governance}

https://doi.org/10.1515/ijsl-2020-2100

\begin{abstract}
This introduction argues that understanding the co-construction of race, language, and nation is essential to understanding liberal democratic governance in today's world. Using the theories and methods of raciolinguistics, we argue that voicing and resemiotization are important discursive processes that people use to reconstitute selves and Others in relation to liberal democratic ideas about national belonging. Specifically, we examine how racialized redefinitions of "the body" are central to how right and left-leaning groups alike (re)define nationhood, albeit for different ends. We foreground an intersectional, international approach to understanding the role of language in constructing race and vice versa as well as the role of social media in how differently positioned groups seek empowerment.
\end{abstract}

Keywords: racialization, language, nationalism, voicing, semiotics, embodiment

\section{Introduction}

This special issue examines how race is constituted in the voicing practices of social actors who seek to control or redefine ideas about difference and belonging. Using the theories and methods of "raciolinguistics" (Alim 2016), we argue that voicing, defined as the discursive recruitment of recognizable social types (Bakhtin 1981; Reyes 2016), is central to how people reconstitute selves and others in relation to liberal democratic ideas about national belonging. We draw attention to places that are experiencing an increasing polarization between socially right and

\footnotetext{
*Corresponding author: Jennifer B. Delfino, Borough of Manhattan Community College (CUNY), New York, USA, E-mail: jdelfino@bmcc.cuny.edu

Maureen Kosse: University of Colorado Boulder, Boulder, Colorado, USA,

E-mail: mary.kosse@colorado.edu
} 
left groups: France, Italy, the Philippines, and the United States. On the one hand, the rise of social and political conservatism in these nations emboldens public displays of purist (white) nationalism. At the same time, groups racialized as other persist in challenging the increased stakes and dangers of neo-nationalist constructions of belonging and difference. Moreover, in the United States, a nation that is characterized by the hegemony of postracial and colorblind racial thinking (Bonilla-Silva 2018; Omi and Winant 1994), so-called "covert" processes of racialization also drive the need to reproduce racial difference and domination for the sake of white comfort (Roth-Gordon et al., this issue) or white virtue (Hill 2008). The goal of this issue, then, is to offer an internationally comparative lens for examining how racialization is voiced as part of different ideologies of governance, belonging, and the control of bodies, and to theorize the outcomes of these processes.

A major theme for this issue is to examine and compare the processes that drive social and political redefinitions of the body in relation to race, language, and ideas about essential difference. We foreground the need for more robust intersectional approaches to raciolinguistics, including the investigation of crosscutting identity categories of difference (i.e., gender, sexuality, and age) as well as examining the discursive signs, practices, and modalities that people are recruiting as a form of social or political empowerment in today's world. As communication is becoming increasingly digitized and global, it is necessary to incorporate more studies that address the impact of these technological shifts on the semiotic construction of race. With a focus on uses of social media, four of the papers in this set allow us to begin to theorize the impact of digital communication on notions of (em)bodied racial difference with attention to the following questions: How is the notion of the body itself reconstituted in relation to race and language on social media? How is race seen, heard, or felt in such emergent contexts of multi-modal communication? What are the perceived threats, opportunities, and challenges to the nation that compel differently positioned groups to speak as selves and others through these and other communicative channels such as narrative (cf. Bonilla and Rosa 2015; Perrino and Jereza, this issue)?

\section{Raciolinguistics: The study of racialization as social-semiotic practice}

Following Urciuoli (1996), Rosa (2019), and others (Dick and Wirtz 2011; Leeman 2004), we define racialization as the process by which particular bodies are constructed as other via essentializing claims about linguistic and cultural difference. 
We understand racializing processes to be semiotically driven. Focusing on the social-semiotic processes of indexicality, iconicity, entextualization, and enregisterment (Irvine and Gal 2000; Mendoza-Denton 2008; Reyes 2016; Rosa 2019; also see Agha 2005; Silverstein 2003), this issue draws on the theories and methods of raciolinguistics to examine how language is used to construct racial difference and the converse: how ideas about race influence linguistic practices and ideologies (Alim 2016).

A semiotic approach not only allows us to compare the discursive construction of race across particular political positions (i.e., "liberal" and "conservative"); it also helps us theorize how commonly held racial ideologies articulate across the political spectrum. As Roth-Gordon, Harris, and Zamora suggest, corporate social media appropriations of African American Language (AAL) do not overtly signal race or racist intent, but still rely on a similar logic of difference and power as farright groups that mobilize explicitly racializing voicing practices such as linguistic mocking to construct the other. As they argue, "White comfort is generated through the avoidance of overt references to racial conflict [...] [and] also through well-worn, familiar, and comfortable reminders of racial difference and domination that are offered at a safe distance from actual black people and contexts of racial violence". Since colorblindness and postracialism are normative racial ideologies in many postcolonial and liberal multicultural contexts today, it is especially important to offer an analytical approach that helps render visible the ideological rootedness of race in shared notions of white entitlement and supremacy. As Flores (2017) argues, for example, language is an emergent site for neoliberal practices of "accumulation-by-dispossession", though it has always characterized colonialism and nationalism as racial projects in the United States and elsewhere.

In further comparing the discursive construction of race across different social-semiotic contexts and modalities, it is evident that language stands in for biologically rooted notions of racial difference (cf. Urciuoli 2001), especially in cases where far-right groups mobilize explicit raciolinguistic ideologies (Flores and Rosa 2015), such as linguistic purism. This is especially evident in Tebaldi's paper, which examines how linguistic purism is recruited in French and U.S. neonationalist discourses about the perceived threat of multiculturalism to a homogeneously imagined white ethno-state. As Tebaldi notes in the case of right-wing French Twitter, such groups use "raciolinguistic tropes to imagine a language of social decline, connecting linguistic purism to racist myths of white genocide and the great replacement". Of particular benefit to raciolinguistics, then, is the theorizing of contemporary discursive constructions of white supremacy in relation to changes in nation-state governance. The concept of "white fragility" (DiAngelo 2011) is especially relevant here, as we see far-right groups 
appropriating the marginality of actual others to express anxieties about the perceived decline of white homogeneity as multiculturalism gains traction in governance and elsewhere.

At the same time, the multicultural state offers a kind of "safe" inclusion to racially minoritized groups without actually disrupting normative racial arrangements such as hegemonic whiteness (Flores 2017; Rosa 2019). That is to say, linguistic and cultural differences are tolerated as long as they do not interfere with the racial project of assimilation; this is especially evident in studies of schooling among racially and linguistically minoritized students (Delfino, this issue; Flores and Rosa 2015; Rosa 2019). As Delfino illustrates in this issue, this sort of "inclusion-but-not-really" precipitates forms of talk back on the part of African American students, who use a linguistic practice called marking to mock white after school instructors attempting to perform discipline. In the process, they weaken the institutional effectiveness of so-called "proper" English by portraying white staff as ineffective at their task relative to the more "articulate” African American adults in their lives. China offers a similar analysis of Black Twitter social media users, who contest white appropriations of culturally meaningful linguistic forms, symbols, and icons.

\section{Voicing selves and others: Embodiments of racial difference}

A raciolinguistic approach grounded in social-semiotic analysis offers an entry point for examining how people (re)position themselves and others through the performance of social "voices" (Bakhtin 1981). Our issue proposes that voicing practices are particularly salient sites for (re)constituting racialized selves and others and for facilitating ideas about language(s) as embodiments of racial difference. Voicing, as a practice, is fundamentally connected to racialized bodies. Raciolinguistics presents us with a crucial fact - that racialized bodies are linked to ways of speaking to the point that one comes to represent the other via processes of raciolinguistic enregisterment (Agha 2005; Flores and Rosa 2015; Rosa 2019). It would not be possible to identify the figure of personhood identified by a voice if that figure and that voice were not already co-naturalized to some degree. In this sense, voicing practices are fundamentally racialized and racializing processes.

Voicing not only marks, but actively entrenches racialized ideologies of sameness and difference. Perrino and Jereza document how Italian and Philippine racial narratives create "exclusionary intimacies" which establish in-group intimacy by ridiculing and excluding others. Similarly, Tebaldi examines how 
French nationalist Twitter constructs racialized speakers of French as "languageless" (Rosa 2019) under the hashtag \#JeSuisCirconflex, connecting raciolinguistic tropes to ideologies of linguistic purism to racist myths of "white genocide”. Delfino explores how African American students recruit semiotic resources of whiteness to mark their instructors as ineffective disciplinarians. RothGordon, Harris, and Zamora analyze how brands on Twitter strategically bleach the association between AAL and blackness to appropriate social capital associated with "black cool".

The papers in this special issue cover voicings across racialized bodies, and across modalities, scaling upward from local practices to broader sociopolitical phenomena. We draw from the project of raciolinguistics, which challenges mainstream discourses that co-naturalize language and the racialized body; in parallel, we must consider how speakers recruit voice as a resource to perpetuate racialized and national ideologies. Weidman (2014) writes that "vocal practices, including everyday speech, song, verbal play, ritual speech, oratory, recitation, can be viewed as modes of practice and discipline that, in their repeated enactment, may performatively bring into being classed, gendered, political, ethnic, or religious subjects". Thus, attention to strategic recruitment of voice may provide insight on how speakers cultivate in-group intimacy by racializing others.

\section{Resemiotization: Intersectionality in and across modalities}

This issue includes a focus on resemiotization, by which we mean the reconstitution of socially meaningful relationships between language and racialized subjectivities. In this regard, the issue draws attention to the need to include an intersectional focus on cross-cutting categories of difference that help reinforce, transform, or challenge existing hierarchies of race. Delfino's paper highlights how African American students draw on hegemonic gender ideologies to disrupt the raciolinguistic pathologization of AAL. China offers a detailed multi-modal discourse analysis that examines the multiple and contested intersections of race, sexuality, and feminism among different Tumblr users, and foregrounds the intersectional construction of an “oppositional gaze”. As these papers show, other ideologies of difference, especially gender, are often used to construct, transform, or challenge existing racial regimes through resemiotizing processes such as enregisterment and entextualization.

Second, resemiotization is not just mediated through the raciolinguistic ideologies participants bring to bear on their voicing practices, but also via the particular modalities they take up in order to do so. A core focus for this issue is 
how social media, which is multi-modal, resemiotizes race in relation to bodies. China's paper documents how Beyoncé is both linguistically and visually recruited by Tumblr users to challenge the hegemonic deracialization of "Bey" as a feminist icon. Roth-Gordon, Harris, and Zamora also use linguistic and image-based analysis to examine how corporate brands deracialize AAL on Twitter by indexically stripping it away from Black bodies. What we see in their product placement is either white bodies or no bodies at all, which helps produce "white comfort" with respect to linguistic appropriation. These papers describe a similar process: language is disembodied from its actual users. In both cases, while race is visually resemiotized, the indexical relationship between language and the bodies racialized as other are ideologically reinforced. In these last two cases, resemiotization helps the powerful retain hegemonic control over racialized representations of selves and others.

Ultimately, this issue approaches resemiotization as a politically contested process between differently positioned groups. While social media has helped to empower voices from the margins (Bonilla and Rosa 2015), it has also emboldened alt-right and neonationalists groups to spread moral panics about the perceived decline of white purity and homogeneity. Such uses and reappropriations of different signs and indexicalities in digital space thus invite further examination of how representations of "race" circulate with particular kinds of semiotic value and power: what is their uptake, and by whom? Who is responding to or challenging the kinds of political mobilizations people are calling for, and how are ideas about race and language changing in this process?

Ultimately, this issue probes the durability of "race" in language and in relation to language with the goal of theorizing its persistence and transformation in relation to different modes of liberal state governance. In suggesting future directions that build off this project, we suggest examining neoliberalism's influence on corporate governance and social media as a site for these particular intersections.

\section{References}

Agha, Asif. 2005. Voicing, footing, enregisterment. Journal of Linguistic Anthropology 15(1). 38-59.

Alim, Samy H. 2016. Introducing raciolinguistics: Racing language and languaging race in hyperracial times. In Samy H. Alim, Arnetha Ball \& John R. Rickford (eds.), Raciolinguistics: How language shapes our ideas about race, 1-30. Oxford, UK: Oxford University Press.

Bakhtin, Mikhail M. 1981. The dialogic imagination. Austin, TX: University of Texas Press. 
Bonilla, Yarimar \& Jonathan Rosa. 2015. \#Ferguson: Digital protest, hashtag ethnography, and the racial politics of social media in the United States. American Ethnologist 42(1). 4-17.

Bonilla-Silva, Eduardo. 2018. Racism without racists: Color-blind racism and the persistence of inequality in America. Lanham, MD: Rowman \& Littlefield.

DiAngelo, Robin. 2011. White fragility. International Journal of Critical Pedagogy 3(3). 54-70. https://libjournal.uncg.edu/ijcp/article/viewFile/249/116.

Dick, Hillary Parsons \& Kristina Wirtz. 2011. Racializing discourses: A special issue of the Journal of Linguistic Anthropology. Journal of Linguistic Anthropology 21(s1). E2-E10.

Flores, Nelson. 2017. From language-as-resource to language-as-struggle: Resisting the cokeification of bilingual education. In Mi-Cha Flubacher \& Alfonso Del Percio (eds.), Language, education, and neoliberalism: critical studies in sociolingustics, 62-81. Bristol, UK: Multilingual Matters.

Flores, Nelson \& Jonathan Rosa. 2015. Undoing appropriateness: Raciolinguistic ideologies and language diversity in education. Harvard Educational Review 85(2). 149-171.

Hill, Jane H. 2008. The everyday language of white racism. New York, NY: Wiley Blackwell.

Irvine, Judith T. \& Susan Gal. 2000. Language ideology and linguistic differentiation.In Paul V. Kroskrity (ed.), Regimes of language: Ideologies, polities, and identities, 35-84. Santa Fe, NM: School of American Research Press.

Leeman, Jennifer. 2004. Racializing language: A history of linguistic ideologies in the U.S. Census. Journal of Language and Politics 3(3). 507-534.

Mendoza-Denton, Norma. 2008. Homegirls: Language and cultural practice among Latina youth gangs. New York, NY: Wiley Blackwell.

Omi, Michael \& Howard Winant. 1994. Racial formation in the United States: From the 1960s to the 1990s. New York, NY: Routledge.

Reyes, Angela. 2016. The voicing of Asian American figures: Korean linguistic styles at an Asian American cram school. In, Samy H. Alim, Arnetha Ball \& John Rickford (eds.), Raciolinguistics: How language shapes our ideas about race. Oxford, UK: Oxford University Press.

Rosa, Jonathan. 2019. Looking like a language, sounding like a race: Raciolinguistic ideologies and the learning of Latinidad. Oxford, UK: Oxford University Press.

Silverstein, Michael. 2003. Indexical order and the dialectics of sociolinguistic life. Language \& Communication 23. 193-229.

Urciuoli, Bonnie. 1996. Exposing prejudice: Puerto Rican experiences of language, race, and class. Boulder, CO: Westview Press.

Urciuoli, Bonnie. 2001. The complex diversity of language in the United States. In Ida Susser \&

Thomas C. Patterson (eds.), Cultural diversity in the United States: A critical reader, 190-205.

New York, NY: Blackwell Publishing.

Weidman, Amanda J. 2014. Anthropology and voice. Annual Review of Anthropology 43. 37-51. 